\title{
Book Revious
}

\section{BRITISH OBSTETRIC AND GYNAECOLOGICAL PRACTICE}

Edited by Sir Eardley Holland, M.D.(Lond.), F.R.C.P., F.R.C.S., F.R.C.O.G., and AlECK BOURNE, M.A., M.B., B.Ch.(Cantab.), F.R.C.S., F.R.C.O.G.

\section{GYNAECOLOGY}

Edited by Aleck Bourne. Second edition. Pp. xii +891 , illustrated. London: William Heinemann (Medical Books) Ltd. I958. I05s. net.

(The obstetric section edited by Sir Eardley Holland is not the subject of this review.)

Professor Jeffcoate's new chapter on disorders of menstruation apparently flows from his pen with such ease that one knows the writing must have been painstaking in the extreme. It is beautifully done and it is not only a delight to read, but it is informative, lucid, scientific, orderly, logical and extremely well illustrated. If it be the tour de force in the book, as I believe it is, it is in good company beside such chapters as Wilfred Shaw's chapter on the ovary and broad ligament revised by John Howkins and John Stallworthy's chapter on genital tuberculosis. These are authoritative and informative. But if these chapters have been picked out, it is not to say that the others are not of a high standard, too, for they are.

This is a book that will, of course, date, because it is so full of detail, but it does faithfully represent the very best in modern British gynaecological practice.

Mr. Bourne and his publishers, as well as his collaborators, are to be congratulated on surpassing even their previous excellent achievement.

\section{E.E.P.}

\section{COMPARATIVE ANATOMY AND PHYSIOLOGY OF THE NOSE AND PARA- NASAL SINUSES}

By Sir Victor Negus, Hon. D.Sc., M.S., F.R.C.S., F.R.C.S.E. F.R.C.S.I. Pp. $x v+402$, with 178 illustrations. Edinburgh: E. \& S. Livingstone Ltd. 1958. 70s.

This is a fascinating book. It will be read with the greatest interest by anatomists, physiologists and rhinologists throughout the world, all of whom will be amazed at the immense amount of factual knowledge contained in it.
Sir Victor has followed up his masterpiece on the comparative anatomy and physiology of the larynx with this counterpart on the nose and sinuses. It may be felt that this second effort does not quite reach the high level attained by the first; nevertheless, it is a very valuable addition to the bibliography of the subject.

The author is the one person capable of tackling the arduous work of reconstructing the famous Onodi collection of human bones which was so badly damaged in I94I. In doing this he has performed a great service; in addition, he has gone much further and has collected a very wide field of interesting research in the whole range of the animal kingdom.

It is a book which will be used in two ways: one for reference to gain knowledge of certain facts not easily found elsewhere and one for browsing througl at one's leisure to pick up bits of delightful new about odd facts and theories. In this latter respect there are many examples, such as the reason why bulls are said (by some persons) not to chase women; the edifying fact that man shares only with the howler monkey, the sifaka, the tree kangaroo, wombat and chamois the occurrence of large frontal sinuses; and the fact that the maxillary sinus in man serves no useful function whatsoever, other than forming the shape of the human face.

Sir Victor has made a sort of enormous scrap album, collecting data from many sources and adding innumerable examples of his own prolonged studies in experimental research. He expresses his own opinion on many important subjects - such as ciliary function, olfaction and the evolutionary history of man, to mention only three-with an authority that will be universally accepted.

It would be churlish for the reviewer to offer any real criticism. It does, however, seem that, although the actual chapters are presented in an orderly sequence, the contents of some are occasionally disjointed and one gets the impression of viewing a kaleidoscope. The very nature of the work makes it impossible for it to be otherwise.

Again, there are bound to be parts not touched on at a length sufficient for all appetites. For example, the remarks on the number of cilia in the nasal mucosa, on metaplasia and on the function of the nose and sinuses in phonation seem rather curtailed.

The volume is beautifully produced and the enormous number of $g$ res very clearly presented.

I.G.R. 